\title{
UNRWA: Challenges for Humanitarian Aid in an Increa- singly Sensitive Political Environment
}

\author{
Laura Ryseck* and Margret Johannsen**
}

\begin{abstract}
The Gaza War once again highlighted the difficult role of the United Nations Relief and Works Agency for Palestine Refugees in the Near East (UNRWA). Since its creation 60 years ago, UNRWA has developed into the largest provider of social services for the Palestinians, as well as into the main employer of Palestinian refugees. However, the agency carries out its work in a highly politicised environment, having led to disapproval of some of its activities and even a general questioning of its work. Especially in the Gaza Strip it has been subject to severe criticism. This article discusses the challenges that the agency is facing in the light of failed peace negotiations, growing demands and a chronic shortage of funds, the increasingly sensitive political environment and the serious humanitarian situation that developed in the aftermath of the Hamas takeover of the Gaza Strip in June 2007.
\end{abstract}

Keywords: Middle East conflict, Palestinians, Israel, refugees, UNRWA, Gaza Strip

Nahostkonflikt, Palästinenser, Israel, Flüchtlinge, UN-Flüchtlingshilfswerk, Gazastreifen

\section{The Making of a Refugee Population}

As a consequence of the violent conflicts triggered by the unsettled Palestine question since 1948 more than two thirds of the nine to ten million Palestinians living today are refugees, many of whom have been displaced more than once. The Palestinians constitute the oldest community of refugees worldwide as well as the largest group of stateless people. One third of the 4.6 million people registered with UNRWA as of 30 June 2008 live in one of the 58 refugee camps supervised by the agency, ${ }^{1}$ which runs schools and health centres as well as distribution centres for food and other items of basic need for the refugees. As the refugee question has remained unsolved, the initial temporary mandate of UNRWA has constantly been extended making it one of the UN's oldest institutions and the largest supplier of social support to the Palestinians. The UN's dedication in support of the Palestinian refugees does not, however, meet with unanimous approval, and is sometimes subject to fairly heavy criticism.

The Gaza Strip has always been the most challenging of UNRWA's five areas of operation - the West Bank, the Gaza Strip, Lebanon, Jordan and Syria - as approximately over three quarters of the population are refugees registered with the organisation, for whom UNRWA is mandated to provide basic services. ${ }^{2}$ Especially in this area of operation, UNRWA has repeatedly been confronted with the accusation of employing members and supporters of Hamas and of giving political cover and support to what has been branded a "terrorist group" by the Israeli government and most of the Western world. ${ }^{3}$

\footnotetext{
Laura Ryseck, M.A., M.P.S. is Doctoral Candidate at the London School of Economics (LSE).

** Dr. Margret Johannsen is Senior Research Fellow at the Institute for Peace Research and Security Policy at the University of Hamburg (IFSH). The authors are grateful for the valuable recommendations of the two anonymous reviewers

1 UNRWA, Total Registered Camp Population as of 30 June, 2008, http://www. un.org/unrwa/publications/pdf/population.pdf.

2 See UNRWA, Gaza refugee camps profile, http://www.un.org/unrwa/refugees/ gaza.html.

3 See UNRWA offers political cover to Hamas, http://www.jpost.com/servlet/Sate
} llite?cid=1235410706632\&pagename=JPost/JPArticle/ShowFull.
On 27 December 2008 Israel started its military campaign "Operation Cast Lead" against the Gaza Strip, only a few days after a six-month truce ended between the state of Israel and Hamas. The confrontation did not only result in a high number of casualties but also contributed to further aggravating the humanitarian situation that, due to the Israeli siege of the territory since Hamas had seized power in the Strip in June 2007, was already severe before. The blockade decisively affected the work of UNRWA as it not only placed strict curbs on imports of non-humanitarian but yet vital goods such as fuel, but also limited the import of goods for humanitarian assistance. ${ }^{4}$ Moreover, in the course of the conflict the agency not only faced accusations of giving shelter to Hamas fighters, but some of its facilities became targets of Israeli attacks, most notably on 6 January 2009 when three shells landed outside an UNRWA school where civilians were seeking shelter, resulting in at least 30 dead and 55 wounded. ${ }^{5}$ To be sure, the extraordinary problems that UNRWA has to cope with in the wake of the recent war $^{6}$ may for a while eclipse the challenges in other areas of operation. Still, the overall situation in the densely populated territory ought to be put in context and seen in the light of developments that reach far back to the root of the refugee problem.

\section{Creation, Mandate and Funding of UNRWA}

In the context of the UN partition plan for the territory of the Mandate of Palestine, the proclamation of the state of Israel, and the first Arab-Israeli war, hundreds of thousands of Palestinian Arabs fled the territory on which the State of Israel was founded in 1948. According to UN estimates, approximately

4 See UNRWA Emergency Appeal 2009, 30 November 2008, p. 10, http://www. reliefweb.int/rw/RWFiles2008.nsf/FilesByRWDocUnidFilename/EGUA-7MCNYN-full_report.pdf/\$File/full_report.pdf.

5 OCHA, occupied Palestinian territory, Gaza Flash Appeal, http://ochaonline. un.org/humanitarianappeal/webpage.asp?Page=1740, p. 7 (footnote 11).

6 See UNRWA, Updated Quick Response Plan for Gaza: An Assessment of Needs Six Months After the War, http://www.un.org/unrwa/donors/docs/Updated QRP_aug09.pdf. 
$726,000^{7}$ refugees found refuge mainly in the West Bank and the Gaza Strip, but also in the neighbouring Arab states; a minority moved on to the Gulf states, to Europe or to the USA.

The refugees were denied the return to Israel. The United Nations tried early on, prior to the signing of the armistice agreements, to identify possible solutions to the refugee question, and finally passed resolution 194 (III) on 11 December 1948. It was to turn into one of the most quoted documents by the United Nations concerning the Palestine conflict. Of special relevance to the refugees was paragraph 11 , which concedes to them the general right to choose between return, naturalization in the host country, or resettlement in a third country. Moreover, they were entitled to lay claim to the return of property or to respective compensation for incurred losses from the state having caused the situation of the refugees. ${ }^{8}$ The constantly raised claim of the refugees, as well as of the Arab governments, that Israel should let the refugees return has, however, always been rejected by all Israeli governments. ${ }^{9}$ The reason is that Israel did not - and up until today does not - consider itself responsible for the fate of the refugees; according to Israel, they were rather victims of a war of aggression by the Arab states. Although this interpretation of the events of 1948 has been strongly contested by a number of Israeli scholars ${ }^{10}$, it serves Israel to reject all sorts of claims for compensation by the refugees who fled or were expelled, and it preserves its constitutionally defined identity as a Jewish state, which it fears would be endangered by a large number of returning refugees.

On the other hand, the neighbouring Arab states which host the refugees reject their naturalisation and legitimise their refusal by referring to the "Right of Return" according to Resolution 194. ${ }^{11}$ However, as the General Assembly can only make non-binding recommendations under international law and accordingly cannot pass legally binding resolutions, a compulsory "Right of Return", on which the refugees themselves insist, cannot be deduced from Resolution 194. Nevertheless, the General Assembly annually renews the resolution. ${ }^{12}$ As a consequence, the different options mentioned for the Palestine refugees of 1948 in paragraph 11 of the resolution have at least the status

7 See Final Report of the United Nations Economic Survey Mission for the Middle, http://domino.un.org/pdfs/AAC256Part1.pdf.

8 See UNDoc. A/RES/194 (III) Palestine-Progress Report of the United Nations Mediator, http://domino.un.org/unispal.nsf/361eea1cc08301c485256cf600606959/ c758572b78d1cd0085256bcf0077e51a!OpenDocument.

9 Only during the early 1950s, roughly 40,000 Palestinians were allowed to return to their areas of origin. These Israeli concessions were, however, not based on an acknowledgement of the "Right of Return", but were measures of family reunions.

10 See Benny Morris, The Birth of the Palestine Refugee Problem, 1947-1949, Cambridge University Press, 1988; Ilan Pappé, The Ethnic Cleansing of Palestine, Oxford: One World, 2006; Although Morris in his seminal work on the origins of the refugee problem denies that there had been a master plan for expelling the Palestinian Arabs from the areas that would become the State of Israel, he does not subscribe to the official narrative that Israel bore no responsibility whatsoever for the birth of the refugee problem. See also: Benny Morris, The Birth of the Palestine Refugee Problem Revisited, 1947-1949, Cambridge: Cambridge University Press, 2003.

11 See Asem Khalil, Palestinian Refugees in Arab States: A Rights-Based Approach, CARIM Research Report, Robert Schuman Centre for Advanced Studies, San Domenico di Fiesole (FI): European University Institute, 2009, pp. 19, 51, http://cadmus.eui.eu/dspace/bitstream/1814/10792/1/CARIM_RR_2009_ 08.pdf.

12 See UN-Doc. A/Res/62/83 Peaceful settlement of the question of Palestine, http:// domino.un.org/UNISPAL.NSF/361eea1cc08301c485256cf600606959/a3188f ecb31aff868525740200571514!OpenDocument. of internationally accepted directives for the settlement of the refugee problem.

To ease the humanitarian emergency situation of the refugees, the United Nations set up a fund for emergency assistance in November 1948, mainly to provide financial support and to coordinate the work of local governments as well as the efforts of international humanitarian organisations. When it became clear that no quick solution to the refugee question in line with Resolution 194 would be implemented, the decision was taken to establish UNRWA to take care of the humanitarian consequences. ${ }^{13}$ The United Nations Relief and Works Agency for Palestine Refugees in the Near East was officially created on 8 December $1949 .{ }^{14}$ It is an institution formally subordinate to the General Assembly and serves to arrange support and work programmes for the Palestinian refugees. Only five per cent of its budget comes from United Nations funds, the remaining funding is secured by donations from member states. The highest contributions come from the United States and the European Commission, as well as a number of European states on a bilateral level.

The agency officially took up its work on 1 May 1950. The mandate, initially limited to three years, has been continuously renewed ever since. The latest renewal is until 30 June $2011 .{ }^{15}$ Although UNRWA developed into one of the UN's oldest institutions and the largest supplier of support to the Palestinians, the three-year interval has been maintained. This serves to symbolise that the work of the relief agency should not be seen as an alternative to a comprehensive political solution of the problem.

\section{The Palestinian Refugees and International Law}

In order to receive UNRWA assistance, the refugees have to register with the agency. As not every refugee automatically qualifies for assistance, UNRWA formulated a working definition of the term "Palestine refugee", which has been specified over the course of the years. Introducing such a working definition was necessary for two reasons, as, first, an authoritative, generally accepted definition of Palestine refugees does not exist, and second, to emphasise the aspect of being in need of help, which is a basic condition for eligibility for assistance. The aspect of being in need of help is of importance due to the mandate of the agency, and, at the same time, shows that the term drafted by UNRWA cannot be considered a comprehensive formula of what defines a "Palestine refugee". In fact, the definition of Palestinian refugees derives from relations to UNRWA rather than the political circumstances that caused the

13 Based on the advice of a specifically created Economic Survey Mission (ESM). See Lex Takkenberg, The Status of Palestinian Refugees in International Law, (Oxford 1998), pp. $25 \mathrm{ff}$.

14 See UN Doc. A/RES/302(IV) Assistance to Palestine Refugees, http://domino. un.org/UNISPAL.NSF/a06f2943c226015c85256c40005d359c/af5f909791de 7fb0852560e500687282! OpenDocument.

15 See UN Doc. A/Res/62/102, http://domino.un.org/UNISPAL.NSF/d9 d90d845776b7af85256d08006f3ae9/49687e908ff033a9852573d700 501d85!OpenDocument. 
exodus. ${ }^{16}$ Hence, there are refugees that do not meet the criteria of being in need of help and do not fall under the mandate of UNRWA, but are still refugees from Palestine and are therefore entitled to the rights guaranteed for in Resolution 194.

Eligible for registration with the organisation are those "persons whose normal place of residence was Palestine between June 1946 and May 1948, who lost both their homes and means of livelihood as a result of the 1948 Arab-Israeli conflict". ${ }^{17}$ The terms used in this definition are clearly defined by UNRWA in its directives (Consolidated Eligibility and Registration Instructions). ${ }^{18}$ In the mid-1960s, the eligibility of all the descendents of registered male refugees to be registered themselves was added to the definition. This amendment constitutes an anomaly in refugee law. The decision to add this amendment is most likely due to political motivation. ${ }^{19}$ Due to the inclusion of descendents and as a result of high birth rates, the number of refugees registered with UNRWA has continuously increased from 914,000 in the year 1950 to around 4.6 million today ${ }^{20}$.

UNRWA is a pure relief organisation. Notwithstanding its informal role of providing refugees with a source of identity by linking, through the documents issued, the individual refugees with their loss" 21 , and through its very existence affirming the justice of the refugees' claims for redress ${ }^{22}$, UNRWA's assigned task is the humanitarian and economic support of the refugees, limited to the operational area of the Gaza Strip, the West Bank, Jordan, Lebanon and Syria. The main goal was to improve the economic situation of the refugees until a political solution would be found. This also reflects in the temporary character of the mandate of the agency. It is neither authorized to address political tasks such as coming up with or implementing a permanent solution with regard to the refugees, nor does it fulfil any international protective function concerning the refugees. This is of importance as the very existence of UNRWA excludes those refugees registered with it from protection under the Geneva Refugee Convention 1951 and the United Nations High Commissioner for Refugees (UNHCR), resulting from article $1 \mathrm{D}$ of the Refugee Convention, which states that it "shall not apply to persons who are at present receiving from organs or agencies of the United Nations other than the United Nations Commissioner for Refugees protection or assistance". ${ }^{23}$

16 See Helena Lindholm Schulz with Juliane Hammer, The Palestinian Diaspora. Formation of identities and politics of homeland, London and New York: Routledge, 2003, p. 36.

17 See UNRWA, Who is a Palestine Refugee?, http://www.un.org/unrwa/refugees/ whois.html.

18 See BADIL Resource Center for Palestinian Residency and Refugee Rights. Closing Protection Gaps. Handbook on Protection of Palestinian Refugees, http://www.badil.org/Publications/Books/Handbook.pdf.

19 Adding the descendants has to be considered a particular concession to the host countries, which feared an end of assistance and an "automatic" solution of the problem as a consequence. See Benjamin Schiff, Refugees unto the Third Generation. UN Aid to Palestinians, New York: Syracuse University Press, 1995, pp. $53 \mathrm{f}$.

20 The numbers are not based on a demographic census but on the registration of the refugees with the agency. See UNRWA, Number of registered refugees, http://www.un.org/unrwa/refugees/pdf/reg-ref.pdf.

21 Helena Lindholm Schulz with Juliane Hammer, The Palestinian Diaspora. Formation of identities and politics of homeland, p. 36.

22 See Robert Bowker, Palestinian Refugees - Mythology, Identity, And the Search for Peace, Boulder: Lynne Reinner Publishers, 2003, p. 148.

23 "Convention relating to the Status of Refugees of 28.7.1951", in Christian Tomuschat (ed.), Menschenrechte. Eine Sammlung internationaler Dokumente zum Menschenrechtsschutz, 2. ed., Bonn: UNO-Verlag, 2002, pp. 494ff.
Hence, the protection of the refugees in the operational area of UNRWA is mainly the responsibility of the host countries, which are dealing with this responsibility in diverse ways. Khalil notes that "the exclusion of Palestinians from international protection mechanisms has rendered the position of millions of Palestinians in host Arab states precarious". With the exception of Syria and Jordan, this is all the more so since in the Palestinians' case "refugeehood" is accompanied by statelessness ${ }^{24}$, whose most visible features are the absence of firm civil rights and lack of recognition under international law. In fact, the highly politicised issue of the Palestinian refugees has to be seen as the main cause for the absence of any regional refugee regime as well as for the very limited implementation of the "Casablanca Protocol" 25 of 1965. Talhami observes that as a consequence, "the refugee experience in various Arab countries and under Israeli rule provided a common pattern of lack of autonomous control and low economic status."26

\section{Context and Challenges}

The different and partially conflicting attitudes of the host countries are rooted in the very fact that UNRWA is working as a humanitarian relief organisation in a highly politicised environment. Due to its structure, the agency is not only liable to the recipients of its assistance but is also dependent on the host countries and the international donor community. Hence, it can hardly escape the influence of regional political events and, forced to engage in the "diplomacy of aid" 27 , has to act within an area of tension between its international legal immunity as a body of the United Nations and the territorial authority and special interest politics of the governments in its operational area.

Thus, in practice, the agency often found itself exposed to attempts by governments to manipulate or exploit it and had to fight for its independence, despite its international immunity - which is similar to those of diplomats - and a number of bilateral agreements with the governments of the host countries. Its work has often been obstructed, the staff hassled, and the claim for immunity of the locally recruited staff has continuously led to disputes. ${ }^{28}$

Further complicating the work of UNRWA was the fact that, due to political developments, the "contact persons" for the agency sometimes changed. In Lebanon for instance, the relief organisation had to collaborate with the Palestinian Liberation Organisation (PLO) since 1969, after the Lebanese government had transferred the administration of the camps to the latter. Similarly, the situation changed after the occupation of the

24 See Khalil, Palestinian Refugees in Arab States: A Rights-Based Approach, p. 50.

25 The "Casablanca Protocol" was an initiative of the Arab League to safeguard the Palestinian refugees' rights in their respective host countries. See UNHCR, Protocol on the Treatment of Palestinian Refugees (Casablanca Protocol), in Collection of International Instruments and Legal Texts Concerning Refugees and Others of Concern to UNHCR (June 2007): Regional Instruments, Volume 3: Africa, Middle East, Asia, Americas. Legal publications, 1 June 2007, p. 153, http://www.unhcr.org/cgi-bin/texis/vtx/search?page=search\&docid=455c73 3b2\&query=Casablanca protocol.

26 Ghada Hashem Talhami, Palestinian Refugees - Pawns to Political Actors, New York: Nova Publishers, 2003, p. 127.

27 See Talhami, Palestinian Refugees - Pawns to Political Actors, p. 147.

28 See Schiff, Refugees unto the Third Generation. UN Aid to Palestinians, pp.7ff. 
West Bank and the Gaza Strip by the Israeli army following the Six-Day-War in 1967. Upon request by Israel, and its promise to support the work of the agency, UNRWA continued its activities in the occupied territories and has continued to do so also after the signing of the Oslo Accords in 1993.

Due to the deteriorating humanitarian situation after 1967, the responsibility of UNRWA was extended by the General Assembly. People expelled and in need of help as a result of the Six-DayWar - the so-called Displaced Persons - could now draw on assistance as well. This affected refugees already registered with the organisation that had to flee again as well as persons that had not yet been registered. ${ }^{29}$ In order to respond appropriately to the special threat to the security and human rights of the Palestinian refugees, the General Assembly furthermore called upon UNRWA to make additional relief efforts in the occupied territories in the case of emergencies. This happened for the first time after the massacres of Sabra and Shatila, following the invasion of Lebanon by Israel in 1982. It led to an increase in the share of international staff for the organisation during the first (1987-1993) and the second Intifada (from 2000), as well as the introduction of specific programmes to monitor the current conflict situation in the occupied territories. ${ }^{30}$ Even though these activities can be seen as protective measures in a certain way, the mandate of the agency is still purely humanitarian at its core. The introduction of these measures reflects rather how the United Nations, using UNRWA, rapidly responded to the Palestinian situation worsening as a consequence of the mounting conflict.

The deep economic crisis in the Palestinian territories, caused by the second Intifada and the ensuing Israeli military operations, made it impossible for UNRWA to perform its tasks by exclusively drawing on its regular budget, as, due to the increasing number of registered refugees, the agency was acting within severe financial restrictions. Although important donors such as the European Union have decisively increased their payments to the general fund of UNRWA since 2001, ${ }^{31}$ the agency still had to balance budget shortfalls by emergency appeals, although with limited success. Between October 2000 and December 2006 the agency, due to insufficient financial contributions, was not able to carry out more than a third of its vital services to the refugees. The situation deteriorated even further in the course of 2007 as a consequence of the blockade of the Gaza Strip and the armed conflict in the Nahr al-Bared refugee camp in Northern Lebanon: UNRWA's planned emergency assistance in the Gaza Strip and the West Bank was only half-covered by the financial engagement of the donor community, and the emergency appeal for Northern Lebanon yielded less than a third of the required funds. ${ }^{32}$

29 See UN Doc. A/RES/2252(ES-V) Humanitarian assistance, http://domino. un.org/UNISPAL.NSF/eed216406b50bf6485256ce10072f637/f7575be79bbc6 930852560df0056fc78!OpenDocument.

30 See BADIL, Closing Protection Gaps. Handbook on Protection of Palestinian Refugees, pp. 51ff.

31 See European Commission, EC support to UNRWA, http://ec.europa.eu/external_relations/occupied_palestinian_territory/docs/ec_unrwa_factsheet_ en.pdf.

32 See UNRWA, UNRWA Finances, http://www.un.org/unrwa/finances/index. html.

\section{Criticism of UNRWA}

Although it was the failure to reach a political solution that led to the constant renewal of the mandate of UNRWA, the organisation has been accused, since the end of the 1960s, of contributing to the perpetuation, or even aggravation, of the refugee problem through its continuing existence. These accusations do not just allude to a self interest of the organisation in perpetuating the refugee problem due to the high number of employees. ${ }^{33}$ They go further by claiming that due to the assistance for the refugees the Arab-Israeli conflict has been kept alive to this very day.

One of the best known advocates of this thesis is Edward Luttwak, who in a famed article in Foreign Affairs accused UNRWA of contributing to half a century of Arab-Israeli violence and of continually delaying a peaceful solution of the conflict. ${ }^{34} \mathrm{He}$ argues that the relatively good supply to the refugees in the camps has prevented any integration into the societies of the host countries as well as further emigration of the refugees. Instead of serving as a stepping stone, the refugee camps have developed into lifetime homes for the refugees, followed by generations of refugee children. Furthermore, the concentration in the camps has contributed to generating a refugee nation and to perpetuating resentments and feelings of revenge of the generation of 1948. According to the author, such an atmosphere makes the adolescent inhabitants of the camps receptive for recruitment in the fight against Israel.

Luttwak's provocative thesis may reflect the charm of realism. However, his argument paints a very simplistic picture of the situation. This is not to deny that in the absence of a solution, the camps have indeed, as Tahami puts it, "become a hothouse for the rising generations of refugee nationalists, an inevitable consequence of the prolonged and alienating refugee experience." 35 However, UNRWA was created in order to serve as crisis management of a humanitarian catastrophe that has a political problem at its core. A solution of this political problem could not and cannot be substituted by UNRWA's humanitarian support, and this has never been its goal anyway. By creating the agency, the United Nations had rather decided, in accordance with the basic values encoded in its Charter, to take over moral responsibility for the refugees, whose situation has to be described as being unique in many respects.

Even without the existence of UNRWA an integration of the refugees into the neighbouring Arab countries would certainly not have taken place to such an extent that the problem would have been solved by itself, as suggested by Luttwak. Only Jordan was willing, after immense initial problems, to integrate a majority of the refugees. In the other neighbouring countries it was more in the interest of the governments to keep the unsolved refugee problem alive as a "blazing wound" in the context of the Israeli-Arab antagonism. Without the support of UNRWA the humanitarian situation of the refugees would most probably have deteriorated, which would have led to even

33 A large majority of the 24.324 employees of UNRWA are Palestine refugees themselves. See UNRWA Organization, http://www.un.org/unrwa/organization/staff.html.

34 Edward Luttwak, "Give War a Chance", Foreign Affairs, Vol. 78, No 4 (July/August 1999), S. 36-44 (42)

35 Talhami, Refugees - Pawns to Political Actors, pp. 147f. 
stronger resentments against the "originator" of the emergency situation. In addition, integration into the host countries does not necessarily mean giving up the legal claim. After all, the claim of recognition of the "Right of Return", on which the refugees insist, also includes the recognition of their situation being the result of an injustice done to them.

Aside from criticism relating to the very existence and mandate of UNRWA, the work of the agency has increasingly become hampered. Also accusations have repeatedly been voiced that it collaborates with, or even gives cover to groups labelled as "terrorist organisations" by Israel and the international community. ${ }^{36}$

As a result of the deterioration of the situation during the two Palestinian upheavals, the relationship between the agency and Israel has increasingly become tense. Especially since the outbreak of the second Intifada in September 2000, there have been complaints by UNRWA about the humanitarian work of the organisation being massively hampered by Israeli measures such as its politics of blockades or the imposition of curfews. The Israeli government on the other hand claimed, for instance, that UNRWA's ambulances were used by terrorists for the transport of weapons and fighters. In this context heavy personal allegations were voiced against Peter Hansen, Commissioner-General of UNRWA between 1996 and 2005³7, who was accused by the Israeli government of following a constant anti-Israeli policy. This partiality would show in unbalanced and disproportionate negative reports about Israel. After some controversial statements by Hansen in 2004, Israel called for an UN-investigation as well as his resignation. In fact, his tenure was not extended the following year due to US instigations. ${ }^{38}$ In July 2005, the US-American Karen Koning Abu Zayd was appointed as his successor. Still, accusations can constantly be heard in the American public about how American taxpayer's money, given to the UNRWA, would indirectly finance Palestinian "terrorists", who would use UNRWA facilities for their purposes and that UNRWA would also employ members of Hamas. ${ }^{39}$

With regards to these accusations the agency obviously faced a dilemma when Hamas won the 2006 Palestinian elections, and especially when it took over control in the Gaza Strip in June 2007. On the one hand, Hamas achieved its victory in free and democratic elections; on the other hand, its legitimacy has been recognized neither by Israel nor by the international community. In any case, UNRWA is not in a position to make political judgements but has to give neutral and impartial

36 For a recent example see James G. Lindsay, Fixing UNRWA. Repairing the UN's Troubled System of Aid to Palestinian Refugees, January 2009, http://www. washingtoninstitute.org/pubPDFs/PolicyFocus91.pdf. For a response to the report see Maya Rosenfeld, Setting the Record Straight, http://www.un.org/unrwa/allegations/index.html.

37 See Peter Hansen, "Wechsel nach Gaza als neue Herausforderung. Das UNRWA und der Friedensprozess im Nahen Osten“, Vereinte Nationen, no.6, 1997, pp. 208-214.

38 See UNRWA head to go against his will, http://news.bbc.co.uk/1/hi/world/ middle_east/4191313.stm.

39 See Ibid.; see also UNRWA violating regulations, http://www.jpost.com/servlet/Satellite?pagename=JPost $\% 2 F J P A r t i c l e \% 2 F S h o w F u l l \& c i d=115919333890$ 1; see also UNRWA. The United Nations Relief and Works Agency for Palestinian Refugees in the Near East. Links to Terrorism, http://israelbehindthenews.com/ pdf/UNRWA.pdf. This report, authored under survey of the 'Israel Resource News Agency“, heavily but dubiously documented accuses UNRWA of being entrapped into terrorist structures and activities. assistance to a specific population group in an environment of most diverse perspectives, claims and expectations. Hence, Hamas turned into the "contact person" for UNRWA in the Gaza Strip, a cooperation that is not free from conflict and tensions, just as is the case with the other governments the agency has to deal with.

However, the working relationship with Hamas, necessary for the sake of humanitarian assistance, helped to fuel the abovementioned accusation and served as justification for attacks on UNRWA facilities during the latest armed confrontation in the Gaza Strip. To this end, the agency was not only accused of giving shelter to Hamas fighters but of attacks on Israel being launched from its facilities, which would make them a legitimate target in the armed confrontation. In fact, even before "Operation Cast Lead", there have been claims that UNRWA should be "an obvious target" in the Gaza Strip, due to the "mutually beneficial relationship" that it has with Hamas. ${ }^{40}$ Even though targeting the agency probably was not necessarily meant to suggest a military attack, this would still be a message to the United Nations, as it, in line with Luttwak's accusations, "perpetuates the Palestinian refugee problem and lends legitimacy to groups like Hamas through UNRWA's continued existence." ${ }^{11}$ Following the Gaza War, and probably as a response to the criticism of employing individuals with loyalties to certain political parties, "the agency's management has warned it may fire employees who violated the organization's nonpartisan policy by affiliating with political factions in Gaza - namely Fatah and Hamas". ${ }^{42}$

\section{Outlook}

Despite all the problems, challenges and accusations that UNRWA has to face, there is ample evidence that the work of the agency is essential for the humanitarian situation of the Palestinian refugees. At the same time, it should not be forgotten that the relief organisation is only providing crisis management services, while a political solution to the refugee question is still indispensable, not just for humanitarian reasons but also because it continues to constitute a source of conflict as long as it remains unresolved.

It is not very likely that the legal claim of the Palestinians concerning the "Right of Return" will be accepted within the framework of a comprehensive settlement. However, a solution that does not care for the "Right of Return" in principle and disregards the element of freedom of choice will probably never be accepted as a just solution, neither by the Palestinians nor by the Arab world. As long as a two-state solution - i.e. one that foresees a Palestinian state alongside the state of Israel as a state for the Jews - is on the agenda of the conflict parties and the international community, a return of the refugees to their 1948 areas of origin does not appear to be a realistic option. Rather,

40 See Asaf Romirowsky, How UNRWA supports Hamas, The Jewish Policy Centre, Fall 2007, http://www.jewishpolicycenter.org/53/how-unrwa-supports-hamas.

41 Ibid.

42 Amira Hass, "UNRWA threatens to fire Gaza employees with declared Hamas, Fatah loyalties", Haaretz, 2 April 2009, http://www.haaretz.com/hasen/ spages/1075344.html. 
some mechanism of resolution that is based on the principles of a limited and controlled return and on compensation and settlement in third countries is needed. On the Palestinian side, this would imply "replacing a tragic past with a hopeful future" 43 , i.e. orientating the quest for a sustainable solution to the refugee problem towards future rights of security, citizenship, and the promise of a life with dignity, thereby removing deeply held beliefs about the right to return to a former homeland from the list of grievances to be addressed on the ground. ${ }^{44}$ These beliefs will not and need not be forgotten, but they could become part of the collective memory which some day, if peace prevails, could be tapped without feeling pain or causing fear. This shift of focus on the Palestinian side, however, would require a change on the Israeli side. By critically confronting their past and the role Israel played in creating the Palestinian refugee problem, Israelis would "work towards Palestinian sensitivities" 45 and pay tribute to the self-respect of the Palestinians who, if their sense of justice was addressed and their sacrifice recognised, could afford realism to take its course. In such a scenario, the notion of "return" could be allowed to take on a new meaning. In a broader sense, 'return' would have to include the unlimited and unrestricted integration of the Palestinian refugees in a new state of Palestine. ${ }^{46}$ Such a state,

43 Mark A. Heller/Sari Nusseibeh, No Trumpets, No Drums: a two-state settlement of the Israeli-Palestinian conflict, New York: Hill and Wang, 1991, p. 87.

44 See Robert Bowker, Palestinian Refugees - Mythology, Identity, and the Search for Peace, Boulder: Lynne Reinner Publishers, 2003, p. 3.

45 See "Interview mit Ilan Pappe am 29. Februar 2000, Haifa University“, in Karin Joggerst, Getrennte Welten - getrennte Geschichte(n)?: zur politischen Bedeutung von Erinnerungskultur im israelisch-palästinensischen Konflikt im Anhang: Interviews mit Benny Morris, Ilan Pappe, Tom Segev, Moshe Zimmermann und Moshe Zuckermann, Münster: Lit, 2002, pp. 116-123 (120).

46 See the mechanism proposed to solve the refugee problem in Article 7 of the Geneva Accord of 2003, The Geneva Accord. A Model Israeli-Palestinian Peace Agreement, http://www.geneva-accord.org/mainmenu/english. however, would have to be capable, with regard to territory, resources and regional cooperation and integration, of offering those who are willing to return a prospect for life that would make it reasonable to renounce the right to return to the "old homes" on the territory of today's Israel, which had been insisted upon for decades. However, any peaceful agreement with Israel requires some sort of national unity government on the Palestinian side, including both Hamas and Fatah. This again also means acceptance and integration of Hamas by the international community, including Israel, into the process of reconstruction in the aftermath of the latest confrontation. Only after unification and empowerment of the Palestinian society, the prerequisites of an agreement with Israel will be given.

Whether or not the refugees are considered to be "at the core" of the "'Palestinian problem'" as Morris ${ }^{47}$ denotes the Israeli-Palestinian conflict, it is safe to say that the refugee problem can only be resolved as part of an overall settlement of the Arab-Israeli conflict. ${ }^{48}$ At the same time, whatever a final peace agreement will look like, without a solution to the refugee question there will be no basis for reconciliation and hence no sustainable solution. Therefore, UNRWA is needed to meet the legitimate claims of the refugees on securing their basic humanitarian needs. Even in the necessary process of empowerment of the Palestinian society the agency can take over an important role by laying the material groundwork for the political process to take place.

47 Benny Morris, The Birth of the Palestine Refugee Problem Revisited, 1947-1949, p. 600.

48 Don Perez, Palestinians, Refugees, and the Middle East, United States Institute of Peace Press 1993, p. 110.

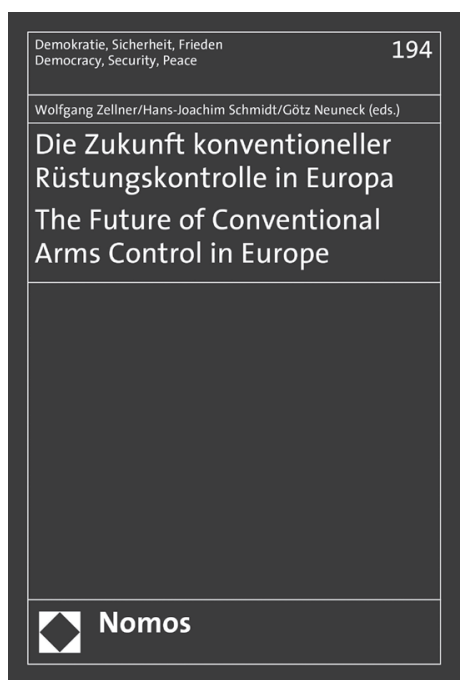

\section{Die Zukunft konventioneller Rüstungskontrolle in Europa. The Future of Conventional Arms Control in Europe}

Herausgegeben von Wolfgang Zellner, Hans-Joachim Schmidt und Götz Neuneck

2009, 560 S., brosch., 89,-€,

ISBN 978-3-8329-4786-6

(Demokratie, Sicherheit, Frieden, Bd. 194)

Der Vertrag über konventionelle Streitkräfte in Europa (KSE) ist ein Kernelement der kooperativen Sicherheitspolitik in Europa. Diese ist jedoch in einer tiefen Krise. In diesem Band analysieren führende Experten aus den USA, Russland sowie anderen europäischen Ländern die Situation und erarbeiten Vorschläge, wie die gegenwärtige Blockade überwunden werden kann. 